\title{
The relationship between midwifery students' acceptance of violence between couples and level of aggression: A multicentered study
}

\author{
Sule Gokyildiz Surucu \\ Dilek Bilgic ${ }^{2}$ \\ Semiha Aydın Ozkan \\ Zekiye Turan ${ }^{5}$

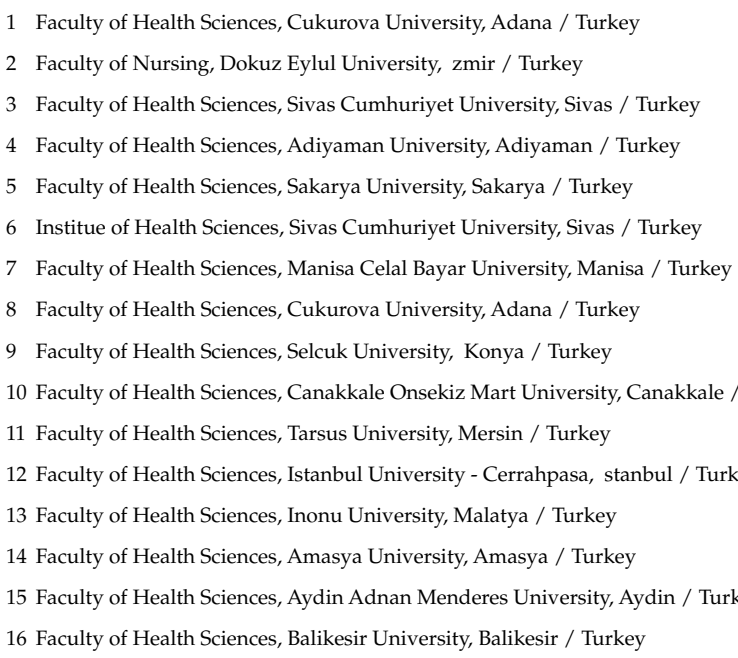

Gulseren Daglar ${ }^{3}$

Handan Guler ${ }^{6}$ (D)

Hulya Demirci ${ }^{7}$ (D) Sultan Alan ${ }^{8}$ (D) Sema Dereli Yilmaz ${ }^{9}$ (D)

Ayten Dinc $^{10}$ (D) Eylem Toker ${ }^{11}$ (D) Husniye Dinc Kaya ${ }^{12}$ (D) Tuba Ucar ${ }^{13}$

Saadet Gonca Mavi Aydogdu ${ }^{14}$ (D) Zekiye Karacam ${ }^{15}$ (D) Selda Yoruk ${ }^{16}$ (D)

Figen Digin $^{17}$ (D) Gokce Isbir ${ }^{18}$ (D) Hasan Huseyin Cam ${ }^{19}$

Citation: Gokyildiz Surucu, S, Bilgic D, Daglar, G, Aydin Ozkan S, Turan Z, Guler H. et. al. The relationship between midwifery students' acceptance of violence between couples and level of aggression: A multicentered study. Health Sci. Q. 2021; 1(1) : 37-43. https://doi.org/10.26900/hsq.1.1.07 


\begin{abstract}
The study was aimed to identify the relationship between acceptance of violence between couples and level of aggression among first and fourth year midwifery students in various universities in Turkey. This is a cross-sectional descriptive study. Personal Information Form, Acceptance of Couple Violence Scale and Aggression Scale were used to collect the data. In the study, the number of the first year students was 1843, and the number of the fourth year students was 1337. There was a weak positive relationship between Aggression Scale and Acceptance of Couple Violence Scale. Acceptance of violence between couples was found to increase with the increase in aggression level. Adolescents' views on aggression between boys and girls are of great importance to provide an opportunity for early intervention and to maintain healthy relationships. It may be suggested that midwifery departments providing health education include these subjects in their curriculum.
\end{abstract}

Keywords: Dating, violence, aggression, flirt, youth

\section{Introduction}

Violence is a phenomenon that has been encountered in every society and in every period of the human history. According to the definition of the World Health Organization (WHO), violence; a danger of injury or injury is death, psychological damage, developmental disorder or deprivation, intentional physical exertion, force or threat to a person, group, or community. Every year, 1.6 million people in the world lose their lives due to violence. Violence is one of the leading causes of death among people aged between 15 and 44 worldwide. It is the cause of death in $14 \%$ of men and $7 \%$ of women. More than death from violence, people's lives are affected by violence-related problems including injury and physical, sexual, reproductive and mental health problems. Violence could be committed by individuals as harming themselves or it could occur among people and societies, as well. Some examples of interpersonal violence include domestic violence, partner violence, flirt violence, and violence committed in care centers [1].

Dating or flirting is defined as two people's maintaining a relationship by fully and evidently participating in social relationships or activities together until marriage or until one or both of the couples wish to end the relationship. Flirt violence is the intentional sexual, physical and psychological attack committed by one of the people dating [2-5]. Puberty is a period which starts from the age of 10 and continues until 20s and which includes biological, psychological, social development and maturing. Some of the main developmental issues in this period include identity, independency, intimacy, sexuality, and success. Adolescents face new relationship patterns in these ages. They want to be approved by their friends by building new and wiser relationships with both genders. Some adolescents who have problems in this period can develop various antisocial behaviors including violence. Individuals react in different ways when there is something wrong about their relationship. For instance, children growing up in violent families cannot learn how to control their anger and demonstrate violent behaviors that can reach to much more dangerous extents in adulthood [4]. It is reported that violence is gradually increasing in the relationships of adolescent and young people with the opposite sex; the relationships are observed to commonly include physical, verbal and sexual violence, jealousy, and controlling behaviors [2,3,5].

This study aims to identify the relationship between acceptance of violence between couples and level of aggression among first and fourth year midwifery department students in Turkey.

\section{Materials and Methods}

\section{Research Design}

The study is cross-sectional descriptive in nature.

\section{Target Population and the Sample}

This study was carried out in midwifery programs in Turkey between January and June 2015. Target population of this study was the 1st year and 4th year students enrolled in the midwifery departments that provided 4-year education through undergraduate programs in faculties and colleagues in Turkey. Except for the private universities, there are 32 midwifery departments in Turkey. Four universities were excluded from the study because they did not have 1 st and 4 th year students. The sample of the study was 3180 students. Of the students' 1843 were first year students and 1337 were fourth year students. The forms were given to the students in an envelope, and they were asked to fill these forms themselves. The forms were administered to 1st year students in the fall semester, and 4th year students in the spring semester, a closer time to graduation. 


\section{Data Collection Tools}

The data were collected through "Personal Information Form", "Acceptance of Couple Violence Scale" (ACVS) and "Aggression Scale" (AS).

\section{Personal Information Form}

This scale includes 19 questions that aimed to identify students' socio-demographic features and their perceptions and attitudes towards violence.

Table 1. Socio-demographic characteristics of the participants

\begin{tabular}{|c|c|c|}
\hline Characteristics & n (3180) & $\%$ \\
\hline \multicolumn{3}{|c|}{ Class } \\
\hline 1.Class & 1843 & 58 \\
\hline 4. Class & 1337 & 42 \\
\hline \multicolumn{3}{|c|}{ Marital Status } \\
\hline Single & 3094 & 97.3 \\
\hline Married & 86 & 2.7 \\
\hline \multicolumn{3}{|c|}{ Place of Birth } \\
\hline Village & 227 & 55 \\
\hline Town & 1203 & $\begin{array}{l}37 \\
87\end{array}$ \\
\hline City & 1750 & 55 \\
\hline \multicolumn{3}{|c|}{ Place of Longest Location } \\
\hline Village & 515 & 162 \\
\hline Town & 1036 & 32.6 \\
\hline City & 1629 & 51.2 \\
\hline \multicolumn{3}{|c|}{ Family Type } \\
\hline Nuclear Family & 2549 & 80.2 \\
\hline Extended Family & 544 & 17.1 \\
\hline Divided Family & 87 & 2.7 \\
\hline \multicolumn{3}{|c|}{ Education Level of Mother } \\
\hline Illiterate & 366 & 11.5 \\
\hline Literate & 97 & 3.1 \\
\hline Primary School & 1873 & 58.9 \\
\hline Secondary School & 397 & 12.5 \\
\hline High School & 365 & 11.5 \\
\hline University & 82 & 2.6 \\
\hline \multicolumn{3}{|c|}{ Working Status of Mother } \\
\hline Yes & 312 & 9.8 \\
\hline No & 2868 & 90.2 \\
\hline \multicolumn{3}{|c|}{ Education Level of Father } \\
\hline Illiterate & 63 & 2 \\
\hline Literate & 36 & 1.1 \\
\hline Primary School & 1370 & 43.1 \\
\hline Secondary School & 575 & 18.1 \\
\hline High School & 786 & 24.7 \\
\hline University & 350 & 11 \\
\hline \multicolumn{3}{|c|}{ Working Status of Father } \\
\hline Yes & 3108 & 97.7 \\
\hline No & 72 & 2.3 \\
\hline
\end{tabular}




\section{Acceptance of Couple Violence Scale}

The scale which was developed by Foshee et al. (1992), and was adapted to Turkish by Sezer (2008). Of the 11 items, 1st, 3rd, and 4th items are related with acceptance of male violence committed to women, 5th, 6 th, and 8th items are related with acceptance of female violence committed to men, and 2nd, 7th, 9th, 10th, and $11^{\text {th }}$ items are related with acceptance of violence between couples generally. The items in the scale are responded on four options as $1=$ strongly disagree, $2=$ disagree, 3 =agree, and $4=$ strongly agree. While higher scores to be obtained from the scale indicate high level of acceptance of violence between couples, lower scores indicate lower acceptance levels [4].

Table 2. Findings about relationship between socio-demographic characteristics of the participants and ACVS/AS

\begin{tabular}{|c|c|c|c|c|c|c|}
\hline \multirow[b]{2}{*}{ Characteristics } & ACVS & Physical Aggression & Verbal Aggression & Anger & Hostility & Indirect Aggression \\
\hline & $\bar{X}_{ \pm \mathrm{SD}}$ & $\bar{X}_{ \pm \mathrm{SD}}$ & $\bar{X}_{ \pm \mathrm{SD}}$ & $\bar{X}_{ \pm \mathrm{SD}}$ & $\bar{X}_{ \pm \mathrm{SD}}$ & $\bar{X}_{ \pm \mathrm{SD}}$ \\
\hline \multicolumn{7}{|l|}{ Class* } \\
\hline 1. Class & $17.45 \pm 6.46$ & $15.93 \pm 6.54$ & $12.85 \pm 3.43$ & $20.56 \pm 5.07$ & $18.42 \pm 5.20$ & $13.28 \pm 4.14$ \\
\hline \multirow[t]{2}{*}{ 4. Class } & $15.81 \pm 6.19$ & $15.28 \pm 6.67$ & $12.55 \pm 3.70$ & $19.92 \pm 5.35$ & $17.44 \pm 5.35$ & $12.82 \pm 4.27$ \\
\hline & $\mathrm{p}<0.05$ & $\mathrm{p}<0.05$ & $\mathrm{p}<0.05$ & $\mathrm{p}<0.05$ & $\mathrm{p}<0.05$ & $\mathrm{p}<0.05$ \\
\hline \multicolumn{7}{|l|}{ Age $^{*}$} \\
\hline 20 and & $17.43 \pm 6.41$ & $16.07 \pm 6.59$ & $12.90 \pm 3.44$ & $20.66 \pm 5.10$ & $18.52 \pm 5.22$ & $13.33 \pm 4.17$ \\
\hline \multirow[t]{2}{*}{21 and } & $16.00 \pm 6.30$ & $15.19 \pm 6.58$ & $12.53 \pm 3.66$ & $19.87 \pm 5.29$ & $17.43 \pm 5.26$ & $12.78 \pm 4.22$ \\
\hline & $\mathrm{p}<0.05$ & $\mathrm{p}<0.05$ & $\mathrm{p}<0.05$ & $\mathrm{p}<0.05$ & $\mathrm{p}<0.05$ & $\mathrm{p}<0.05$ \\
\hline \multicolumn{7}{|l|}{ Marital Status* } \\
\hline Single & $16.78 \pm 6.38$ & $15.67 \pm 6.57$ & $12.73 \pm 3.55$ & $20.31 \pm 5.19$ & $18.04 \pm 5.25$ & $13.08 \pm 4.18$ \\
\hline \multirow[t]{2}{*}{ Married } & $15.84 \pm 6.91$ & $15.23 \pm 7.43$ & $12.58 \pm 3.64$ & $19.55 \pm 5.75$ & $17.17 \pm 5.75$ & $12.92 \pm 5.00$ \\
\hline & $\mathrm{p}>0.05$ & $\mathrm{p}>0.05$ & $\mathrm{p}>0.05$ & $\mathrm{p}>0.05$ & $\mathrm{p}>0.05$ & $\mathrm{p}>0.05$ \\
\hline \multicolumn{7}{|l|}{ Place of Birth** } \\
\hline Village & $18.32 \pm 6.95$ & $15.64 \pm 6.05$ & $12.78 \pm 3.45$ & $20.25 \pm 4.99$ & $17.82 \pm 4.79$ & $12.96 \pm 3.77$ \\
\hline Town & $16.69 \pm 6.08$ & $15.58 \pm 6.41$ & $12.69 \pm 3.50$ & $20.45 \pm 5.08$ & $18.13 \pm 5.09$ & $13.05 \pm 4.25$ \\
\hline \multirow[t]{2}{*}{ City } & $16.60 \pm 6.51$ & $15.72 \pm 6.79$ & $12.75 \pm 3.59$ & $20.19 \pm 5.31$ & $17.96 \pm 5.44$ & $13.11 \pm 4.22$ \\
\hline & $\mathrm{p}<0.05$ & $\mathrm{p}>0.05$ & $\mathrm{p}>0.05$ & $\mathrm{p}>0.05$ & $\mathrm{p}>0.05$ & $\mathrm{p}>0.05$ \\
\hline \multicolumn{7}{|l|}{$\begin{array}{l}\text { Place of Longest } \\
\text { Location** }\end{array}$} \\
\hline Village & $17.30 \pm 6.17$ & $15.49 \pm 6.28$ & $12.59 \pm 3.51$ & $20.62 \pm 5.35$ & $18.24 \pm 5.18$ & $13.23 \pm 4.09$ \\
\hline Town & $16.74 \pm 6.25$ & $15.71 \pm 6.44$ & $12.75 \pm 3.51$ & $20.40 \pm 5.05$ & $18.15 \pm 5.06$ & $13.07 \pm 4.27$ \\
\hline \multirow[t]{2}{*}{ City } & $16.60 \pm 6.55$ & $15.68 \pm 6.79$ & $12.75 \pm 3.58$ & $20.12 \pm 5.25$ & $17.86 \pm 5.42$ & $13.03 \pm 4.19$ \\
\hline & $\mathrm{p}>0.05$ & $\mathrm{p}>0.05$ & $\mathrm{p}>0.05$ & $\mathrm{p}>0.05$ & $\mathrm{p}>0.05$ & $\mathrm{p}>0.05$ \\
\hline \multicolumn{7}{|l|}{ Family Type ${ }^{* *}$} \\
\hline Nuclear Family & $16.59 \pm 6.38$ & $15.75 \pm 6.63$ & $12.73 \pm 3.59$ & $20.29 \pm 5.26$ & $17.98 \pm 5.35$ & $13.11 \pm 4.25$ \\
\hline Extended Family & $17.54 \pm 6.5$ & $15.34 \pm 6.25$ & $12.68 \pm 3.39$ & $20.37 \pm 4.97$ & $18.17 \pm 4.82$ & $12.93 \pm 3.98$ \\
\hline \multirow[t]{2}{*}{ Divided Family } & $16.89 \pm 6.05$ & $15.14 \pm 7.65$ & $12.85 \pm 3.42$ & $19.85 \pm 5.07$ & $17.92 \pm 5.59$ & $12.94 \pm 4.18$ \\
\hline & $\mathrm{p}<0.05$ & $\mathrm{p}>0.05$ & $\mathrm{p}>0.05$ & $\mathrm{p}>0.05$ & $\mathrm{p}>0.05$ & $\mathrm{p}>0.05$ \\
\hline
\end{tabular}

\section{Aggression Scale}

The scale was developed by Buss and Perry (1992), and was adapted to Turkish by Can (2002). The scale has 34-items and has five sub-dimensions named "physical aggression", "verbal aggression", "anger", "hostility", and "indirect aggression". The scale is a 5-point likert type and the responses include 1=extremely uncharacteristic, 2=somewhat uncharacteristic,
$3=$ neither uncharacteristic nor characteristic, $4=$ somewhat characteristic, and 5=extremely characteristic [6].

\section{Ethical Considerations}

The ethical approval was obtained from the NonInterventional Research Ethics Board of Cukurova University. The aim of the study was explained to the 
participants, and their written consent was obtained prior to the attendance of the research. The participants were assured that the information they provided would remain confidential and that they could leave the study at any time.

Table 3. Findings about relationship between several characteristics and ACVS/AS

\begin{tabular}{|c|c|c|c|c|c|c|}
\hline \multirow{2}{*}{ Characteristics } & ACVS & $\begin{array}{c}\text { Physical } \\
\text { Aggression }\end{array}$ & $\begin{array}{c}\text { Verbal } \\
\text { Aggression }\end{array}$ & Anger & Hostility & $\begin{array}{c}\text { Indirect } \\
\text { Aggression }\end{array}$ \\
\hline & $\bar{X} \pm \mathbf{S D}$ & $\bar{X} \pm \mathbf{S D}$ & $\bar{X} \pm \mathbf{S D}$ & $\bar{X} \pm \mathbf{S D}$ & $\bar{X} \pm \mathbf{S D}$ & $\bar{X} \pm \mathbf{S D}$ \\
\hline \multicolumn{7}{|c|}{ Education Level of Mother** } \\
\hline Illiterate & $17.34 \pm 6.36$ & $15.10 \pm 6.19$ & $12.64 \pm 3.52$ & $20.05 \pm 5.23$ & $17.66 \pm 4.83$ & $13.01 \pm 4.02$ \\
\hline Literate & $17.56 \pm 5.74$ & $15.52 \pm 6.21$ & $12.87 \pm 3.45$ & $20.62 \pm 5.32$ & $17.77 \pm 5.13$ & $12.74 \pm 3.83$ \\
\hline Primary School & $16.54 \pm 6.31$ & $15.61 \pm 6.55$ & $12.67 \pm 3.58$ & $20.27 \pm 5.23$ & $18.00 \pm 5.34$ & $13.02 \pm 4.28$ \\
\hline $\begin{array}{l}\text { Secondary } \\
\text { School }\end{array}$ & $16.68 \pm 6.26$ & $16.02 \pm 6.81$ & $12.67 \pm 3.38$ & $20.25 \pm 4.95$ & $18.21 \pm 5.40$ & $13.15 \pm 4.12$ \\
\hline High School & $16.55 \pm 6.42$ & $16.06 \pm 7.14$ & $13.17 \pm 3.63$ & $20.52 \pm 5.25$ & $18.13 \pm 5.24$ & $13.38 \pm 4.25$ \\
\hline \multirow[t]{2}{*}{ University } & $19.43 \pm 8.80$ & $15.89 \pm 6.34$ & $12.54 \pm 3.49$ & $20.56 \pm 5.41$ & $18.62 \pm 5.31$ & $13.20 \pm 3.92$ \\
\hline & $\mathrm{p}<0.05$ & $\mathrm{p}>0.05$ & $\mathrm{p}>0.05$ & $\mathrm{p}>0.05$ & $\mathrm{p}>0.05$ & $\mathrm{p}>0.05$ \\
\hline \multicolumn{7}{|c|}{ Working Status of Mother* } \\
\hline Yes & $16.51 \pm 6.76$ & $15.52 \pm 6.78$ & $12.82 \pm 3.42$ & $20.29 \pm 5.28$ & $18.03 \pm 5.28$ & $13.02 \pm 4.09$ \\
\hline \multirow[t]{2}{*}{ No } & $16.79 \pm 6.36$ & $15.68 \pm 6.58$ & $12.72 \pm 3.56$ & $20.29 \pm 5.19$ & $18.01 \pm 5.27$ & $13.08 \pm 4.21$ \\
\hline & $\mathrm{p}>0.05$ & $\mathrm{p}>0.05$ & $\mathrm{p}>0.05$ & $\mathrm{p}>0.05$ & $\mathrm{p}>0.05$ & $\mathrm{p}>0.05$ \\
\hline \multicolumn{7}{|c|}{ Education Level of Father** } \\
\hline Illiterate & $18.40 \pm 6.89$ & $14.52 \pm 6.08$ & $13.46 \pm 3.83$ & $19.67 \pm 4.88$ & $17.75 \pm 5.39$ & $12.52 \pm 3.60$ \\
\hline Literate & $16.92 \pm 5.75$ & $14.00 \pm 6.19$ & $12.31 \pm 2.60$ & $18.50 \pm 4.38$ & $16.39 \pm 4.63$ & $12.25 \pm 3.89$ \\
\hline Primary School & $16.78 \pm 6.31$ & $15.50 \pm 6.48$ & $12.65 \pm 3.58$ & $20.32 \pm 5.22$ & $17.89 \pm 5.19$ & $13.00 \pm 4.21$ \\
\hline $\begin{array}{l}\text { Secondary } \\
\text { School }\end{array}$ & $16.80 \pm 6.33$ & $15.60 \pm 6.49$ & $12.84 \pm 3.39$ & $20.22 \pm 5.16$ & $18.16 \pm 5.30$ & $12.96 \pm 4.12$ \\
\hline High School & $16.19 \pm 6.03$ & $16.04 \pm 6.65$ & $12.85 \pm 3.66$ & $20.35 \pm 5.25$ & $18.20 \pm 5.30$ & $13.24 \pm 4.28$ \\
\hline \multirow[t]{2}{*}{ University } & $17.58 \pm 7.45$ & $15.90 \pm 7.20$ & $12.46 \pm 3.44$ & $20.46 \pm 5.25$ & $18.07 \pm 5.47$ & $13.33 \pm 4.26$ \\
\hline & $\mathrm{p}<0.05$ & $\mathrm{p}>0.05$ & $\mathrm{p}>0.05$ & $\mathrm{p}>0.05$ & $\mathrm{p}>0.05$ & $\mathrm{p}>0.05$ \\
\hline \multicolumn{7}{|c|}{ Working Status of Father* } \\
\hline Yes & $16.77 \pm 6.42$ & $15.68 \pm 6.61$ & $12.73 \pm 3.55$ & $20.30 \pm 5.91$ & $18.02 \pm 5.28$ & $13.07 \pm 4.19$ \\
\hline \multirow[t]{2}{*}{ No } & $16.29 \pm 5.56$ & $14.89 \pm 6.21$ & $12.54 \pm 3.46$ & $19.89 \pm 5.76$ & $17.71 \pm 4.79$ & $13.08 \pm 4.54$ \\
\hline & $\mathrm{p}>0.05$ & $\mathrm{p}>0.05$ & $\mathrm{p}>0.05$ & $\mathrm{p}>0.05$ & $\mathrm{p}>0.05$ & $\mathrm{p}>0.05$ \\
\hline \multicolumn{7}{|c|}{ Witnessing Violence* } \\
\hline Yes & $16.78 \pm 6.33$ & $15.76 \pm 6.72$ & $12.77 \pm 3.54$ & $20.46 \pm 5.16$ & $18.22 \pm 5.29$ & $13.19 \pm 4.25$ \\
\hline \multirow[t]{2}{*}{ No } & $16.73 \pm 6.47$ & $15.53 \pm 6.46$ & $12.69 \pm 3.57$ & $20.05 \pm 5.27$ & $17.72 \pm 5.23$ & $12.91 \pm 4.13$ \\
\hline & $\mathrm{p}>0.05$ & $\mathrm{p}>0.05$ & $\mathrm{p}>0.05$ & $\mathrm{p}<0.05$ & $\mathrm{p}<0.05$ & $\mathrm{p}>0.05$ \\
\hline \multicolumn{7}{|c|}{ Violence by parent* } \\
\hline Yes & $17.02 \pm 6.38$ & $17.40 \pm 7.24$ & $13.35 \pm 3.66$ & $21.51 \pm 5.29$ & $19.21 \pm 5.39$ & $14.12 \pm 4.31$ \\
\hline \multirow[t]{2}{*}{ No } & $16.69 \pm 6.40$ & $15.21 \pm 6.35$ & $12.57 \pm 3.50$ & $19.98 \pm 5.13$ & $17.70 \pm 5.19$ & $12.80 \pm 4.13$ \\
\hline & $\mathrm{p}>0.05$ & $\mathrm{p}<0.05$ & $\mathrm{p}<0.05$ & $\mathrm{p}<0.05$ & $\mathrm{p}<0.05$ & $\mathrm{p}<0.05$ \\
\hline \multicolumn{7}{|c|}{ Violence topic was covered in the lessons* } \\
\hline Yes & $16.22 \pm 6.13$ & $15.56 \pm 6.55$ & $12.75 \pm 3.58$ & $20.24 \pm 5.19$ & $17.96 \pm 5.30$ & $13.00 \pm 4.23$ \\
\hline \multirow[t]{2}{*}{ No } & $17.54 \pm 6.69$ & $15.80 \pm 6.66$ & $12.70 \pm 3.51$ & $20.37 \pm 5.23$ & $18.08 \pm 5.22$ & $13.18 \pm 4.16$ \\
\hline & $\mathrm{p}<0.05$ & $\mathrm{p}<0.05$ & $\mathrm{p}<0.05$ & $\mathrm{p}<0.05$ & $\mathrm{p}<0.05$ & $\mathrm{p}<0.05$ \\
\hline
\end{tabular}




\section{Analysis of the Data}

The data of the study were analyzed using SPSS 20.0 for Windows package programming. In addition to the descriptive statistical criteria (means, standard deviations, minimum and maximum values and percentages), t-test (independent samples t-test) and ANOVA were used in comparing the scale scores. The relationship between the scales was analysed using correlation analysis [7]. 1843 were first year students and 1337 were fourth year students. $57.8 \%$ of the participants stated that they witnessed violence and $20.5 \%$ were exposed to violence by their mother or father, they also stated that they were exposed mostly to psychological violence (47\%). $59.4 \%$ of the participants stated that violence topic was covered in the courses and $51 \%$ of these students stated that they covered this topic during their university education.

An evaluation of the participants' ACVS and AS scores according to their socio-demographic features showed that there were no significant differences in terms of their marital status, and the place they lived longest ( $p>0.05$ ). An evaluation of the participants' ACVS and AS sub-scales according to the participants' grade level showed that there was a significant difference between the first and fourth year students. First year students' acceptances of violence and aggression levels were higher. An evaluation of ACVS and AS sub-scales according to the participants' age shows that there was a significant difference between violence, and aggression level and age $(\mathrm{p}<0.05)$. Students in lower age group were found to have higher violence and aggression levels. A significant difference was detected in ACVS according to the place of birth $(\mathrm{p}<0.05)$. It was found that those who were born in a village had higher ACVS mean scores than those who were born in a town or city. There was a significant difference in ACVS according to the type of family $(p<0.05)$. ACVS mean scores of the participants living in an extended family were found to be higher (Table 2). According to the evaluation of ACVS and AS according witnessing violence, there was no difference in terms of ACVS, but there was a significant difference in terms of anger and hostility sub-scales of AS. The participants who witnessed violence were found to have higher anger and hostility mean scores. All AS subscale scores of the participants who were subjected to violence by their parents were found to be higher. There was a significant difference between being subjected to violence and AS scores $(\mathrm{p}<0.05)$ (Table 3$)$. An analysis of the relationship between ACVS and AS sub-scales showed that there was a positive and weak relationship between acceptance of violence and aggression levels.

\section{Discussion}

A variety of harmful effects on each of the individual partners in the dating relationship of adolescents and young adults is reported to be associated with aggression and violence. These effects include lower self-esteem, reduced self-worth, increased self-blame, anger, hurt, and anxiety [8]. Studies indicate that partner violence is an important social problem [9-17].

In their study involving 1st year and 4th year nursing students, Aslan et al. (2008) reported that 4th year students were subjected to more violence and committed more violence [9]. The present study found that there was a decrease in acceptance of violence rates with the increase in age and grade levels of the students. Unlike the study conducted by Aslan et al., this study did not include committing or being subjected to violence cases. Instruction of this issue in the participants' courses might have had positive contributions. Foshee et al. (2005) found that partner violence was higher in those having low socio- economic level and mothers with low education level. A study investigating the effect of place of living on the dating violence in America reported that young people living in South America had higher dating violence rates in comparison to the young people living in other areas. According to the researchers, this case might result from the fact that the south part has a dominant violence culture and more traditional gender roles [18]. Studies that compare people living in rural areas and cities demonstrate that dating violence rates were higher in people living in rural areas; and the authors explained this case as well with gender roles [19]. The present study shows similarity with previous studies because those who were born in rural areas were found to have higher acceptance of violence scores.

Studies show that witnessing violence or being subjected to violence at home affects individuals' violence and aggression behaviours. Pradubmook-Sherer (2011) conducted a study with 1296 young people aged between 14 and 19 and found that those punished by their parents were more subjected to partner violence; and those with higher financial levels and families with higher education levels were less subjected to partner violence [20]. Black et al. (2015) found that young people who were subjected to violence at home, at school, and in society tended to accept partner violence more [21]. Gover, Kaukinen \& Fox (2008) reported that those subjected to violence and domestic violence in childhood experienced more partner violence [12]. In their study including high school students, Earnest and Brandy (2016) found that those who were subjected to violence at home, who witnessed violence, and who did 
not feel safe at school were subjected to more partner violence [22]. This study found that those exposed to violence in their families had higher aggression levels.

\section{Conclusion}

The participants' acceptance of violence levels was low and there was a positive, slight relationship with their aggression levels. The students' acceptance level decreased with the increase in their age and grade levels. Views of young adults forming a major part of young population and how much they accept or approve violence in their dating relationships are of importance so that solutions to this issue could be found.

\section{Acknowledgements}

We would like to thank to all of the participants. This study was presented as an oral presentation at the The 8th World Conference on Educational Sciences in Madrid on February 2016.

\section{Funding}

This study was not funded by any organisation.

\section{Conflict of interest}

There are no conflicts of interest with respect to the authorship and/or publication of this article.

\section{References}

1. World Health Organization 2002, World Report on Violence and Health.

2. Kepir-Savoly DD, Ulas O, Demirtas-Zorbaz S. Factors that influence level of couple violence acceptance. Turkish Psychol Counseling Guidance J. 2014;5(42):173-83.

3. Kilincer AS, Tuzgol Dos M. Perceived abuse in romantic relationships among university students. Turkish Psychol Counseling Guidance J. 2014;5(42):160-72.

4. Sezer O. The adaptation of acceptance of couple violence scale into Turkish: Validity and reliability studies. J Faculty Educ. 2008;9(16):1-15

5. Uluocak S, Gokulu G, Bilir O. A strategic starting point for the elimination of violence against women: Intimate partner violence. Int J Human Sci. 2014;11(2):362-87. https://doi.org/10.14687/ijhs. v11i2.2942.

6. Can S. The reliability and validity of aggression questionnaire in Turkish population. Speciality Thesis, Gulhane Military Medical Academy, Istanbul. 2002.

7. Ozdamar K. Biostatistic with SPSS. 5th ed. Eski ehir: Kaan Publishing; 2003.

8. Cornelius TL, Sullivan KT, Wyngarden N, Milliken JC. Participation in prevention programs for dating violence beliefs about relationship violence and intention to participate. J Interpers Violence. 2009;24(6):1057-78. https://doi.org/10.1177/0886260508319363.

9. Aslan D, Vefikuluçay Yılmaz D, Zeynelo lu S, Erdost T, Temel F. The study of determine to exposure flirt violence, apply flirt violence and views about this subject of 1 st and 4 th year students in two nursing school in Ankara. Technical Report on the Public Health Foundation and Hacettepe University Women's Problems Research and Application Center. 2008.

10. Brown LK, Puster K L, Vazquez EA, Hunter HL, Lescano CM. Screening practices for adolescent dating violence. J Interpers Violence. 2007;22(4):456-64. https://doi. org $/ 10.1177 / 0886260506296987$.

11. Cauffman E, Feldman SS, Jensen LA, Arnett JJ. The (un)acceptability of violence against peers and dates. J Adolesc Res. 2000;15(6):65273. https://doi.org/10.1177/0743558400156003.

12. 12. Gover AR, Kaukinen C, Kathleen A. The relationship between violence in the family of origin and dating violence among college students. J Interpers Violence. 2008;23(12):1667-93. https:/ / doi.org/10.1177/0886260508314330.

13. Harned MS. A multivariate analysis of risk markers for dating violence victimization. J Interpers Violence. 2002;17(11):1179-97. https:/ /doi.org/10.1177/088626002237401.

14. Josephson WL, Proulx JB. Violence in young adolescents' relationships: A path model. J Interpers Violence. 2008;23(2):189208. https://doi.org/10.1177/0886260507309340.

15. Laporte L, Jiang D, Pepler DJ. The relationship between adolescents' experience of family violence and dating violence. Youth \& Society. 2009;43(1):3-27. https://doi.org/10.1177/0044118X09336631.

16. Luthra R, Gidycz CA. Dating violence among college men and women evaluation of a theoretical model. J Interpers Violence. 2006;21(6):717-31. https://doi.org/10.1177/0886260506287312.

17. Martsolf DS, Draucker CB, Stephenson PL. Patterns of dating violence across adolescence. Qual Health Res. 2012;22(9):1271-83. https:/ / doi.org/10.1177/1049732312449388.

18. Foshee VA, Ennett ST, Bauman KE, Benefield T, Suchindran C. The association between family violence and adolescent dating violence onset does it vary by race, socioeconomic status, and family structure? J Early Adolesc. 2005;25(3):317-44. https://doi. org/10.1177/0272431605277307.

19. Marquart B, Nannini D, Edwards R. Prevalence of dating violence and victimization: Regional and gender difference. Adolescence. 2007;42(168):645-57.

20. Pradubmook Sherer P. Youth attitudes toward dating violence in Thailand. Int J Offender Ther Comp Criminol. 2011;55(2):182-206. https://doi.org/10.1177/0306624X09360659.

21. Black BM, Chido LM, Preble KM, Weisz AN, Yoon JS, DelaneyBlack V. Violence exposure and teen dating violence among African American youth. J Interpers Violence. 2015;30(12):2174-95. https:/ / doi.org/10.1177/0886260514552271.

22. Earnest AA, Brady SS. Dating violence victimization among high school students in Minnesota: Associations with family violence, unsafe schools, and resources for support. J Interpers Violence. 2016; 31(3):383-406. https://doi.org/10.1177/0886260514555863 